\title{
Eliza Grzelak, W poszukiwaniu Edenu. Językowo-kulturowy obraz współczesnego polskiego ogrodu ozdobnego. Kreacja czasu i przestrzeni, Wydawnictwo Officina TUM, Gniezno 2008, ss. 311
}

Rozprawę Elizy Grzelak uznać należy bez wątpienia za interesującą i bardzo potrzebną. Otrzymaliśmy książkę zrodzoną z wielkiej pasji i gruntownej wiedzy na temat ogrodu. Zwraca uwagę klarowność stylu i piękno języka Autorki. Podziw budzi też strona edytorska publikacji.

Książka składa się z pięciu rozdziałów. W rozdziale wprowadzającym (Wprowadzenie, s. 9-40) Autorka formułuje założenia i cele badawcze, charakteryzuje przedmiot pracy (określenia i nazwy odnoszące się do roślin, artefaktów, czynności pielęgnacyjnych i założeń ogrodowych), wskazuje też podstawę materiałową, którą stanowią popularnonaukowe teksty drukowane na łamach prasy ogrodniczej (siedem tytułów z lat 1989-2007: „Działkowiec”, „Kwietnik”, „Mój Piękny Ogród”, „Ogrody”, „Ogródki”, „Zieleńce”, „Magia Ogrodów”).

Zauważalny jest pewien brak „rygoryzmu” obowiązującego w pracach naukowych, co skutkuje brakiem istotnej informacji na temat liczby wykorzystanych tekstów i ich kwalifikacji gatunkowych, brakuje także sygnałów dotyczących oryginalności wybranych pism (można przecież przypuszczać, że niektóre z nich są przekładami tekstów obcych). W dalszych rozdziałach informacje genologiczne pojawiają się, ale sygnalizuję właściwy im „stan rozproszenia" (czytelnik odnajduje je w różnych miejscach monografii).

Podstawowym założeniem metodologicznym pracy jest teza, że „odrębna grupa społeczna, powiązana odrębnymi relacjami społecznymi tworzy własne teksty, które budują indywidualny system komunikacyjny, czyli stanowią podstawę własnego sposobu mówienia" (s. 16).

Wśród sformułowanych celów opracowania głównymi są: analiza kodu wspólnotowego służącego komunikacji ogrodniczej i jego zdefiniowane. Autorka ujmuje go jako „kod służący porozumiewaniu się grupy społecznej ludzi 
zajmujących się profesjonalnie lub amatorsko ogrodami współczesnymi (tj. po roku 1989)” (s. 12). Zadaniem, jakie sobie wyznacza jest także „wypracowanie spójnej metody badań oraz prezentacji językowego obrazu świata, metody łączącej dotychczasowe ustalenia w zakresie: waloryzacji, profilowania i kategoryzacji" (s. 13).

We Wprowadzeniu Autorka informuje też o wyborze metody badawczej i preferencjach metodologicznych (przyjmuje wersję kognitywizmu w ujęciu Jerzego Bartmińskiego). Należy jednak zaznaczyć, że nie wnosi w zasadzie własnego aparatu pojęciowo-terminologicznego (choć pojawiają się próby redefinicji). Pozostaje przy pojęciach i terminach: „wspólnota komunikatywna”, „kategoryzacja”, „profilowanie”, „waloryzacja”. Pozwala to uniknąć chaosu znamionującego wiele prac autorów sięgających do nowych teorii.

Kluczowe w pracy pojęcie ,językowego obrazu ogrodu” wymagało odniesienia do teorii językowego obrazu świata (JOS). Przyjęta przez Autorkę definicja odpowiada deklarowanemu we wstępie dążeniu do wypracowania modelu opisu językowego obrazu świata komplementarnego wobec zastanych stanowisk badawczych (Jerzego Bartmińskiego i Ryszarda Tokarskiego). Jest to: ,struktura pojęciowa utrwalona w strukturze danego języka [...] realizująca się za pomocą tekstów, [...] łącząca wiedzę utrwaloną w języku z wiedzą presuponowaną przez formy językowe, zawartą jednak tym razem nie tylko w przekonaniach, mitach i rytuałach społecznych, ale także w wiedzy profesjonalnej, specjalistycznej, charakterystycznej dla danej wspólnoty komunikatywnej" (s. 22).

Rozdział II to obszerny, liczący 125 stron, słownik „określeń kreujących czas i przestrzeń we współczesnym polskim ogrodzie ozdobnym”. Struktura pracy, w której słownik stanowi integralną część monografii (wyprzedzającą rozdziały analityczne), znamienna jest dla obszernych monografii antropoi toponomastycznych. W przypadku ocenianej rozprawy można dyskutować nad słusznością decyzji Autorki w tej kwestii.

Słownik został uporządkowany tematycznie: pierwszą część stanowi „Świat roślin”, drugą - „Człowiek w ogrodzie”, trzecią - „Nazwy założeń ogrodowych".

Hasła słownikowe (około 700) we wszystkich tych częściach mają jednolitą konstrukcję - definicje budowane są według tego samego klarownego schematu (nazwa, opis, rola danego elementu w kreacji czasu i przestrzeni). Daje tu o sobie znać bogate doświadczenie leksykograficzne Autorki. W części I słownika artykuł hasłowy objaśniający zarówno deskrypcje jednostkowe, jak i określenia kategoryzujące dotyczące roślin, zawiera informacje zawarte w analizowanych tekstach popularnonaukowych i uruchamiane we wspólnotowej komunikacji ogrodników amatorów. Przedstawia je Autorka w sta- 
łym, fasetowym porządku. Układ ten jest zgodny ze sposobem opisu roślin w tekstach popularnonaukowych (nazwa, występowanie, pokrój i wielkość, liście, kwiaty etc.). Odpowiedni dobór i układ faset przyjęła Autorka także dla określeń kategoryzujących. W II i III części słownika „Człowiek w ogrodzie" i , Nazwy założeń ogrodowych” zachowano również fasetowy porządek (nazwa // określenie obiektu, opis obiektu, funkcja kreacyjna). Różnorodność wyznaczania funkcji kreacyjnych w każdej z trzech części słownika tłumaczy niejednorodność samego materiału (różny zakres leksykalny, różna struktura formalna, różna przynależność funkcjonalna).

W całym słowniku przyjęła Autorka adekwatny system odsyłaczy (zdeterminowany założeniem, że definicja hasłowa ma odzwierciedlać wspólnotowy obraz ogrodu). Powiązane są m.in. hasła bliskoznaczne i homonimiczne.

Sposób objaśniania materiału w słowniku nie jest w pełni zgodny z rozumieniem definicji kognitywnej zaproponowanej przez Jerzego Bartmińskiego, co tłumaczyć może zarówno przedmiot analiz (przekaz popularnonaukowy, konieczność operowania elementami wiedzy naukowej i potocznej), jak i podstawa materiałowa (prasa popularnonaukowa) wykorzystana przez Autorkę. Problemy metodologiczne (wymóg adekwatności treściowej i adekwatności strukturalnej definicji obrazującej językowy obraz świata) rozwiązywać ma przyjęta przez nią koncepcja wspólnoty komunikatywnej (twórcy i odbiorcy analizowanych tekstów, tj. ogrodnicy amatorzy). Niezupełnie jasno wyeksplikowane (lub potraktowane nieco pobieżnie) są w pracy relacje: kod wspólnotowy, służący komunikacji ogrodniczej: profesjolekt oraz socjolekt; wspólnota komunikatywna: grupa dyskursywna.

Rozdział III o niebanalnym tytule Piękno ukryte w systemie ma charakter analityczny. Zaprezentowana tu - nadzwyczaj sprawna - wieloaspektowa analiza lingwistyczna (formalna, semantyczna, genetyczna) materiału zawartego w słowniku dowodzi znacznego zróżnicowania i ogromnego bogactwa określeń kreujących czas i przestrzeń.

Rozdział IV pt. Obraz słowem malowany - językowo-kulturowa kreacja ogrodu (s. 209-276) przynosi przekonującą interpretację kluczowych zjawisk: konceptualizacji oraz werbalizacji przestrzeni i czasu. Każda z prezentowanych kategorii (faset) kreuje je bezpośrednio bądź pośrednio, statycznie bądź dynamicznie. Pochylając się z zamysłem interpretacyjnym nad księgą ogrodu, Autorka ma świadomość (co pokazała dobitnie już w rozdziale analitycznym) zakotwiczenia się w jego przestrzeni tworów językowych reprezentujących znacznie zróżnicowane formalnie i funkcyjnie wzorce kategorialne.

Posumowaniem rozprawy jest rozdział V Wspótczesny polski Eden. Jest to doskonale napisane zakończenie książki, przynoszące najważniejsze wnioski i uogólnienia. Jako szczególnie wartościowa jawi się próba wykazania 
uniwersalności badanego fenomenu. Zaproponowany model, uwzględniający fasety: archetypowość ogrodu, kreacja czasu i przestrzeni, waloryzacja, metaforyzacja, relacje człowiek - ogród, wspiera ostateczne wnioski dotyczące badanego kodu jako „uniwersalnej wspólnoty komunikatywnej (kulturowej)” i uniwersalności pojęcia ogrodu polskiego.

Echem dobrej pracy naukowej jest merytoryczna dyskusja, też stawianie pytań. Książka Elizy Grzelak z pewnością do tego skłania. Zgadzając się z tezą o uniwersalności obrazu ogrodu polskiego, chciałoby się jednak zapytać, czy i w jakim stopniu reprezentacja leksykalna przedstawiana przez Autorkę pozostaje niezależna od determinantów historyczno-cywilizacyjnych i etniczno-kulturowych.

Monografia Elizy Grzelak będzie z pewnością inspiracją i zachętą do dalszych badań, także - co chciałabym mocno podkreślić - ujęć kontrastywno-komparatywnych.

Irena Sarnowska-Giefing 